\title{
Effect of Initial Microstructures on the Properties of Ferrite-martensite Dual-phase Pipeline Steels with Strain-based Design
}

\author{
Yueyue Hu, Xiurong Zuo*, Rutao Li, Zhanzhan Zhang \\ School of Physics and Engineering, Zhengzhou University, \\ Daxue North Road, 75, CEP 450052, Zhengzhou, China
}

Received: October 18, 2011; Revised: January 15, 2012

\begin{abstract}
This study aims to investigate the effect of initial microstructures on the properties of ferritemartensite dual-phase pipeline steels with strain-based design. For this purpose, the as-received acicular ferrite steels were first austenitized at $920^{\circ} \mathrm{C}$ for 15 minutes followed by air cooling and water quenching to produce ferrite-pearlite and ferrite-martensite microstructure, respectively. Subsequently, the steels with ferrite-pearlite, ferrite-martensite and as-received acicular ferrite microstructure were intercritically annealed at $820^{\circ} \mathrm{C}$ for 10 minutes followed by water quenching to produce three different ferrite-martensite dual-phase microstructures. Tensile tests, Vickers hardness and Charpy impact tests were carried out to investigate the mechanical properties. Scanning electron microscope was used to analyze the microstructures and tensile fractographs. The results showed that all the tensile specimens of these three different ferrite-martensite dual-phase steels fractured in ductile mode, however, their microstructures and mechanical properties varied significantly. By contrast, the ferrite-martensite dual-phase steel derived from acicular ferrite initial microstructure had optimal combination of the strength, toughness and deformability, which provided a good candidate for the pipeline steels with strain-based design used in severe geological environments.
\end{abstract}

Keywords: dual-phase steel, ferrite-martensite, intercritical annealing, deformability

\section{Introduction}

Steels composed of hard-phase martensite or bainite imbedded in a soft-matrix of ferrite are usually referred to as dual-phase steels ${ }^{1-4}$, which are widely used in the automobile industry to reduce weight and save fuel ${ }^{5,6}$. This kind of combination makes them possess continuous yielding, low yield strength, high tensile strength, high initial work-hardening rates, superior uniform and total elongation compared to other high-strength low alloy (HSLA) steels at a given strength level ${ }^{7-10}$. At present, the usual methods to produce dual-phase steels are either intercritical annealing ${ }^{3,4,7,8}$ or thermomechanical control process (TMCP) $)^{5,11,12}$.

With the rapid industrial growth, large amounts of energy resources are needed. Nowadays, pipeline is the most economic and effective means of transporting oil and natural gas. Pipeline technology is aiming at large diameter, high operating pressure and long-distance. Longdistance pipeline inevitably goes through severe geological environments, such as earthquake, landslide and debris flow. These displacement control loads require pipeline steels have not only high strength and toughness, but also good deformability which is approximately evaluated by low yield ratio and high uniform elongation. At present, the acicular ferrite microstructure is widely used in high grade pipeline steels which are based on the stress design to offer

*e-mail: zuoxiurong@126.com good strengths and toughness. However, the yield ratio of acicular ferrite pipeline steels is relatively high ${ }^{13,14}$, leading to poor deformability. Therefore, steel makers turn their attention to the strain-based design pipeline steels to obtain an optimal combination of high strength, high toughness and good deformability. Due to the characteristic properties of the dual-phase steels such as better deformability than other HSLA steels of similar strengths and the successful using in the automobile industries, this type of dual-phase steel inspires steel makers and provides a good candidate for the strain-based design pipeline steels ${ }^{15,16}$. In the past, some researches discussed about the effect of many factors on the properties of ferrite-martensite dual-phase (FMDP) steels, such as martensite morphology ${ }^{17,18}$, martensite amounts ${ }^{19}$, the tempering and carbon content of ferrite and martensite ${ }^{20,21}$. Moreover, attentions have been devoted to the effect of different initial microstructures on the austenitization during intercritical annealing of dual-phase steels ${ }^{22,23}$. However, most of the work focused on the dual-phase steels which were used in the automobile industry. There were few studies focusing on the dual-phase steels used for pipelines, especially for the initial microstructures including acicular ferrite affect the properties of the FMDP pipeline steels.

In this study, steels with ferrite-pearlite, ferritemartensite and acicular ferrite microstructure were subjected to intercritical annealing to produce FMDP steels used for pipelines with strain-based design. Tensile tests and 
microstructural investigation were carried out to analyze the effect of these three initial microstructures on the properties of these FMDP steels.

\section{Experimental procedure}

The chemical composition of the experimental steel is presented in Table 1. It was supplied in the form of $21 \mathrm{~mm}$ thick hot-rolled sheet with acicular ferrite microstructure.

With an aim to investigate the effect of initial microstructures before intercritical annealing on the properties of the FMDP steels, three different heat-treatment schedules were used: a) hold at $920{ }^{\circ} \mathrm{C}$ (austenite region) for 15 minutes, followed by air cooling, reheat to $820{ }^{\circ} \mathrm{C}$ (ferrite plus austenite region) for 10 minutes, and water quench; b) hold at $920{ }^{\circ} \mathrm{C}$ for 15 minutes, followed by water quenching, reheat to $820{ }^{\circ} \mathrm{C}$ for 10 minutes, and water quench; and c) hold at $820^{\circ} \mathrm{C}$ for 10 minutes, and water quench. The $820{ }^{\circ} \mathrm{C}$ intercritical temperature and the 10 minutes holding time were designed in accordance with the manufacturing process in the factory. The procedures are represented schematically in Figure 1. Specimens were coded as steel A, steel B and steel C, which were corresponding to the ultimate FMDP steels obtained by the heat treatment (a), (b) and (c).

Microstructures of heat-treated specimens were examined using a JSM-6700F scanning electron microscope (SEM) to compare the differences in the ultimate FMDP steels. To study the mechanical behaviors of the FMDP steels, room-temperature tensile tests were conducted using a MTS 810 servo-hydraulic machine with the length of the tensile specimens paralleling to the rolling direction. Three tensile specimens were tested for each group of ultimate FMDP steels, and the average values were given. Charpy impact tests were carried out on standard Charpy V-notch bars of $55 \mathrm{~mm}$ length in the transverse direction using a standard pendulum-type impact testing machine. Vickers hardness values were measured using a HVS-50 microscopic Vickers hardness tester. Martensite volume fraction and

Table 1. Chemical composition of the investigated steel wt. (\%).

\begin{tabular}{cccccccccc}
\hline $\mathbf{C}$ & $\mathbf{S i}$ & $\mathbf{M n}$ & $\mathbf{P}$ & $\mathbf{S}$ & $\mathbf{N i}$ & $\mathbf{C r}$ & $\mathbf{M o}$ & $\mathbf{N b}$ & $\mathbf{T i}$ \\
\hline 0.046 & 0.12 & 1.5 & 0.011 & 0.001 & 0.18 & 0.14 & 0.16 & 0.056 & 0.009 \\
\hline
\end{tabular}

ferrite grain size were measured on at least ten micrographs of each group of ultimate FMDP steels. The statistical errors of the martensite volume fraction and ferrite grain size were within \pm 10 pct. Besides, tensile fracture surfaces were also studied under SEM to analyze the mode of fracture.

\section{Results and Discussion}

\subsection{Initial microstructures before intercritical annealing}

Figure 2 presents the initial microstructures before intercritical annealing. Figure 2 a shows the air-cooled microstructure after austenization, which contains about 6-8 vol.\% pearlite embedded in the coarse polygonal ferrite. Besides, many carbides particles are found in the ferrite grains and on the ferrite grain boundaries. Figure $2 b$ shows the water-quenched microstructure after austenization, which mainly contains ferrite, mantensite and bainite. Figure 2c shows the as-received acicular ferrite microstructure. This acicular ferrite structure is characterized by irregular boundaries and various size grains distributing in a chaotic manner with random orientations. Many previous investigations revealed that the acicular ferrite consisted of substructure and high density of dislocations ${ }^{13,24}$.

\subsection{Dual-phase microstructures}

The SEM micrographs of the FMDP microstructures obtained by water quenching from intercritical annealing at $820{ }^{\circ} \mathrm{C}$ for 10 minutes are given in Figure 3. Figure 3a and $\mathrm{d}$ show the FMDP microstructure derived from the ferrite-pearlite microstructure. Figure $3 b$ and e show the FMDP microstructure derived from the ferrite-martensite microstructure. Finally, the FMDP microstructure in Figure $3 \mathrm{c}$ and $\mathrm{f}$ was derived from the acicular ferrite microstructure. These micrographs clearly showed the martensite morphology, amount, distribution, and the ferrite grain size were markedly different. Based on the previous researches, the substructure of the martensite in the present work was essentially lath type ${ }^{18,25}$, but few microtwins also existed $^{25,26}$. Besides, it can be seen from Figure 3 a to $c$ that the amount of martensite increased while the ferrite grain size decreased.

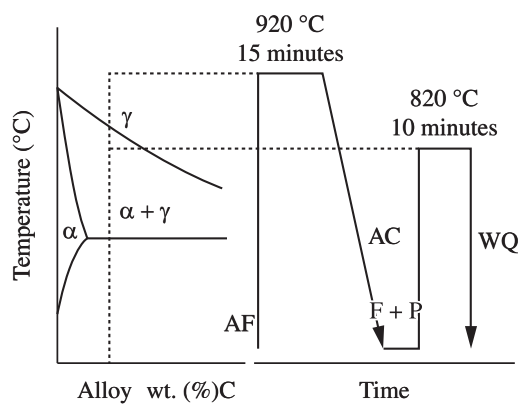

(a)

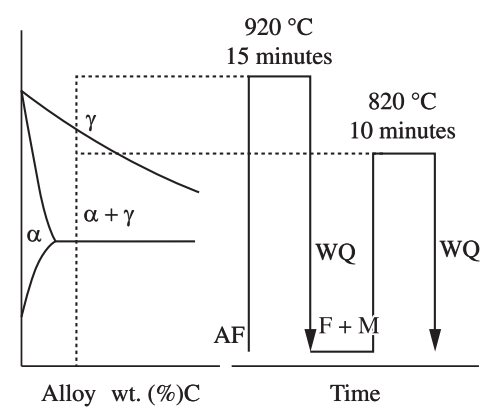

(b)

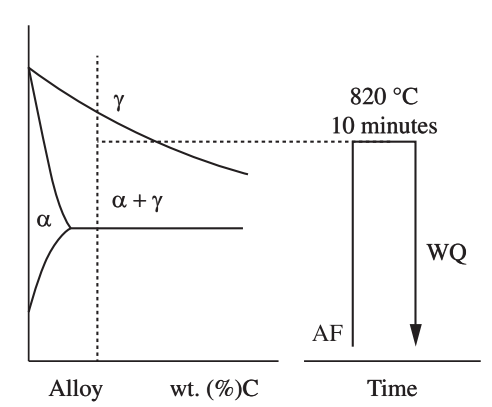

(c)

Figure 1. Schematic representation of heat-treatment schedules for a) steel A; b) steel B; and c) steel C. 
As shown in Figure 3a, the martensite islands are found to be distributed on coarse polygonal ferrite grain boundaries, the triple points of ferrite and within the grain in the steel A. It is not hard to understand the martensite morphology is mainly dominated by the austenitization on the initial microstructures during intercritical annealing. When the initial ferritepearlite structure was reheated to the intercritical region, the cementite in the pearlite was spheroidized. Then, the austenite nucleated inside the pearlite colonies and on the pearlite colony boundaries. Meanwhile austenite was nucleated on the ferrite-ferrite grain boundaries ${ }^{22,27,28}$. Besides, the carbides in the ferrite grains also offered nucleation sites for austenite in the present study. Subsequently, these austenite transformed to martensite islands upon water quenching. Manganese is referred to as an important alloying element which enhances the austenite hardenability and promotes martensite formation $^{4,27,29}$. During intercritical annealing, manganese in the ferrite moved to the boundary and diffused into the austenite, and formed a manganese-rich rim in the austenite boundary which had higher hardenability than the center of the austenite. After water quenching, the manganese-rich rim transformed to martensite rim while the center transformed to other phases, as shown in Figure 3d.

As Figure $3 b$ shown that the martensite has two types of morphologies which are martensite islands and fibrous martensite in the ferrite matrix in the steel B. When the initial ferrite-martensite structure was reheated to the intercritical region, austenite nucleated on the prior martensite laths and bainite lath boundaries, ferrite-ferrite boundaries and carbide particles. After water quenching, the austenite nucleated on the ferrite boundaries and the carbide particles transformed to matensite islands. While, the austenite nucleated on the prior martensite laths and bainite lath boundaries, grew along these lath boundaries, and subsequent water quenching transformed them to fibrous martensites ${ }^{18,30}$, as clearly shown in the Figure $3 \mathrm{e}$. The martensite morphology in the steel B was not all fibrous, differed from that reported in previous investigations $s^{17,30}$. That was because the initial microstructure did not wholly consist of martensite, which was determined by the low hardenability of the investigated steel.

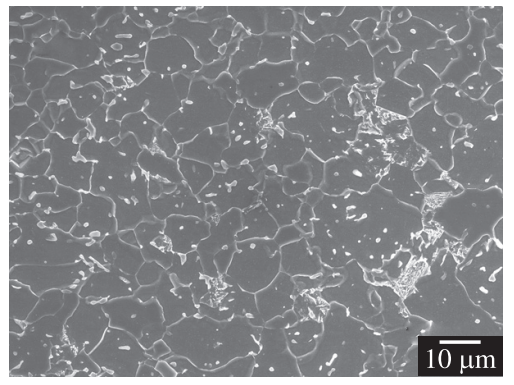

(a)

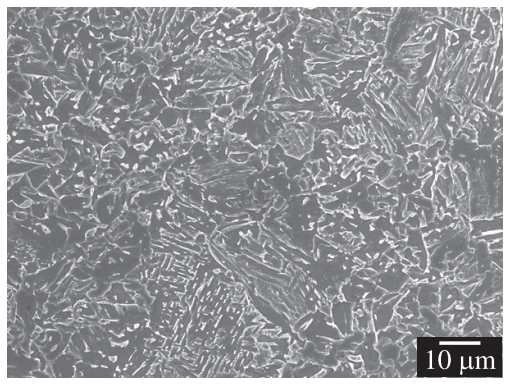

(b)

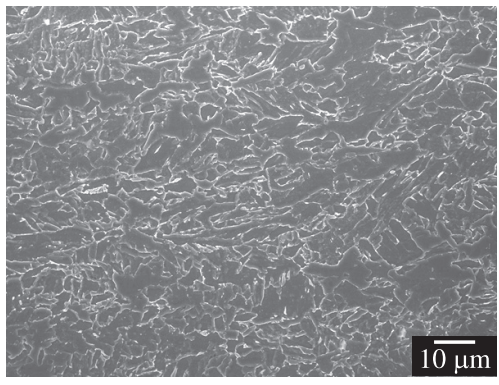

(c)

Figure 2. SEM micrographs of initial microstructures of a) ferrite-pearlite; b) ferrite-martensite; and c) acicular ferrite.

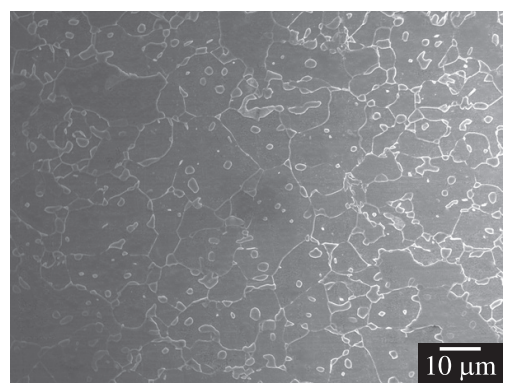

(a)

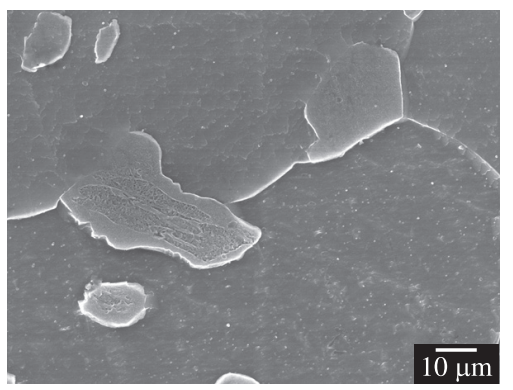

(d)

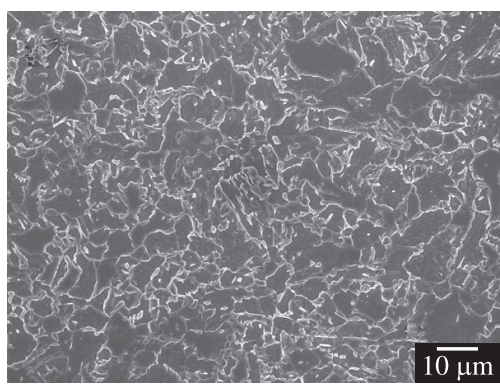

(b)

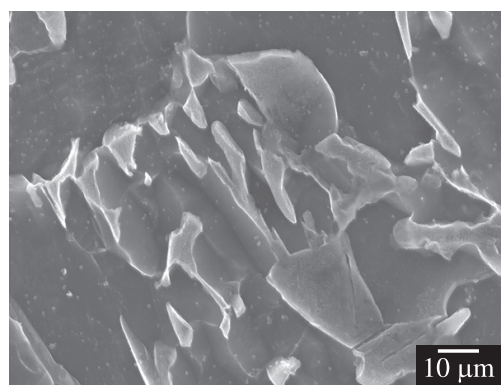

(e)

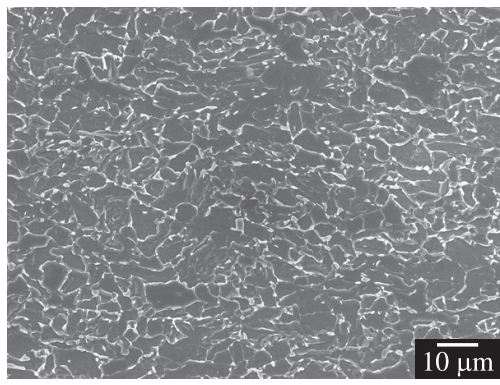

(c)

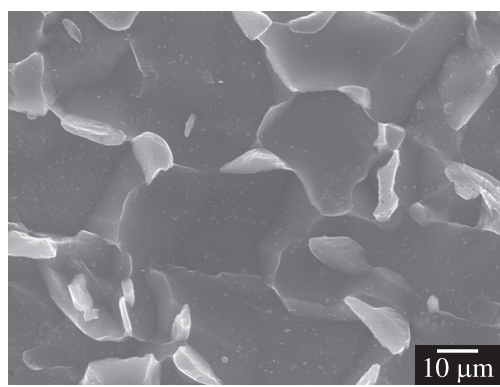

(f)

Figure 3. SEM micrographs of the FMDP microstructures (a, d) steel A derived from ferrite-pearlite microstructure, (b, e) steel B derived from ferrite-martensite microstructure, $(\mathrm{c}, \mathrm{f})$ steel $\mathrm{C}$ derived from acicular ferrite microstructure. 
As shown in Figure 3c, the fine martensite islands distribute uniformly on the ferrite boundaries in steel $\mathrm{C}$. In the two phase region, irregular and jagged boundaries of the acicular ferrite offered well-dispersed and abundant nucleation sites for austenite. With time extension, the austenite continued to nucleate and grow, and then formed a quasi-net array around the ferrite grains. After water quenching, the austenite transformed to fine and welldispersed martensite islands around the ferrite. It can be seen clearly that the morphology of martensite islands around the ferrite in Figure 3f. When the initial acicular ferrite structure was reheated to the intercritical region, the substructure (ferrite lathes) and high density of dislocations in the acicular ferrite (non-equiaxial ferrite) annihilated. Therefore, the initial acicular ferrite grains transformed to polygonal ferrite (equiaxed ferrite) upon water quenching.

\subsection{Mechanical properties}

Engineering stress-strain curves of steel A, steel B and steel C with FMDP microstructures are shown in Figure 4. It can be seen that all the three curves exhibited continuous yielding and rapid initial work hardening. However, tensile properties varied significantly with the initial microstructures, which can be attributed to the differences of the martensite morphologies, distributions, volume fraction and the ferrite grain size, etc. According to the previous results, the continuous yielding in the FMDP steels was attributed to the high density of mobile dislocations introduced during the austenite transforming to martensite ${ }^{8,31}$. Meanwhile, the dislocation density in the ferrite regions adjacent to martensite

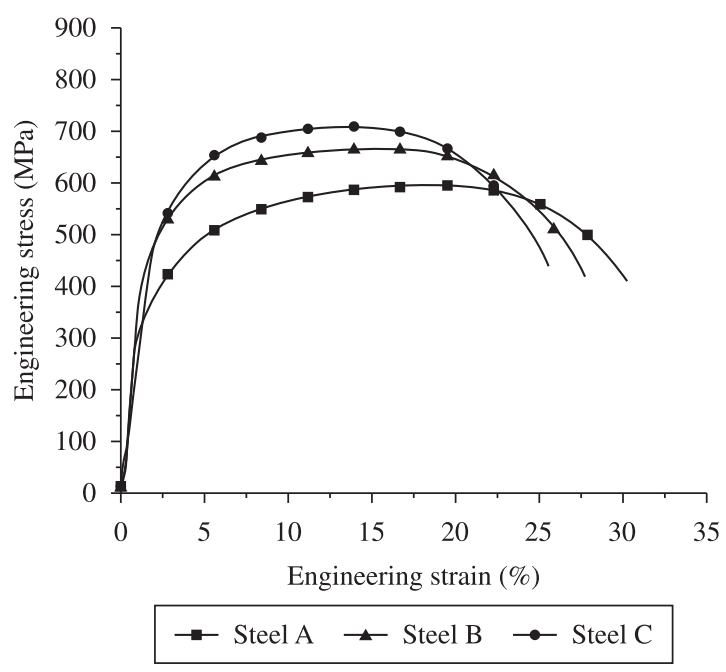

Figure 4. Engineer stress-strain curves of FMDP steels derived from different initial microstructures. particles was higher than that in the ferrite interior regions ${ }^{21}$. The detailed mechanical properties of steel A, B and C are summarized in Table 2.

From the Table 2, it can be seen that from steel A to steel $\mathrm{C}$, the yield strength, tensile strength, hardness, impact energy and yield ratio increased while the uniform and total elongation slightly decreased. Among these specimens with different FMDP microstructures, steel A exhibited the highest uniform elongation and the lowest yield ratio, but its yield strength, hardness and impact energy were the lowest, which could not meet the requirements of HSLA pipeline steels. Even though the uniform elongation of $13.5 \%$ and yield ratio of 0.68 were not as good as steel A and B, steel $\mathrm{C}$ exhibited high hardness of $223 \mathrm{HV} 10$, yield strength of $477 \mathrm{MPa}$, tensile strength of $704 \mathrm{MPa}$ and impact energy of $310 \mathrm{~J}$, which were still much better than other HSLA pipeline steels. By contrast, the steel $\mathrm{C}$ derived from the acicular ferrite microstructure not only had the highest strengths and toughness, but also had good deformability, which met the requirements of the strain-based pipeline steels well.

The martensite volume fractions and the ferrite grain size of the three FMDP steels are shown in Table 3. It indicated that from steel A to steel $\mathrm{C}$, the martensite volume fraction increased while the ferrite grain size decreased. Steel C produced from acicular ferrite microstructure had the highest martensite volume fraction and the finest ferrite grains, which could account for its excellent properties. This result was corresponding to the previous works ${ }^{32}$, which revealed that the yield and tensile strength increased with the percent of martensite increasing for the FMDP steels.

The representative fractographs of the tensile fracture surfaces of steels A, steel B and steel C are presented in Figure 5. These three fracture surfaces revealed that all specimens fractured in ductile mode with the presence of dimples which were due to the microvoids nucleation and coalescence. For such FMDP microstructures, microvoids usually formed at the inclusions, ferrite-martensite interface, separation of adjacent martensite particles and locally deformed martensite particles $^{8}$, in addition, some formed in the ferrite grains ${ }^{17}$. These three figures also showed some deep and big holes in the tensile fracture surfaces, which may be attributed to martensite or inclusion cracking ${ }^{3,8,33}$.

Table 3. Martensite volume fraction and ferrite grain size of experimental FMDP steels (average values).

\begin{tabular}{ccc}
\hline Specimen & $\begin{array}{c}\text { Martensite volume fraction } \\
(\boldsymbol{\%})\end{array}$ & $\begin{array}{c}\text { Ferrite grain size } \\
(\boldsymbol{\mu \mathbf { m } )})\end{array}$ \\
\hline Steel A & 16.1 & 8.6 \\
Steel B & 18.6 & 5.5 \\
Steel C & 20.5 & 4.5 \\
\hline
\end{tabular}

Table 2. Summary of mechanical properties of FMDP steels derived from different initial microstructures (average values).

\begin{tabular}{cccccccc}
\hline Specimen & $\begin{array}{c}\text { Hardness } \\
(\mathbf{H V 1 0})\end{array}$ & $\begin{array}{c}\text { Yield strength } \\
(\mathbf{M P a})\end{array}$ & $\begin{array}{c}\text { Tensile strength } \\
(\mathbf{M P a})\end{array}$ & $\begin{array}{c}\text { Yield } \\
\text { ratio }\end{array}$ & $\begin{array}{c}\text { Uniform } \\
\text { elongation }(\boldsymbol{\%})\end{array}$ & $\begin{array}{c}\text { Total elongation } \\
(\boldsymbol{\%})\end{array}$ & $\begin{array}{c}\text { Charpy impact energy } \\
\left(\mathbf{- 2 0} \mathbf{C}^{\circ} \mathbf{( \mathbf { J } )}\right.\end{array}$ \\
\hline Steel A & 167 & 315 & 584 & 0.54 & 19.7 & 29.4 & 158 \\
Steel B & 185 & 410 & 666 & 0.62 & 15.6 & 24.5 & 246 \\
Steel C & 223 & 477 & 704 & 0.68 & 13.5 & 22.7 & 310 \\
\hline
\end{tabular}




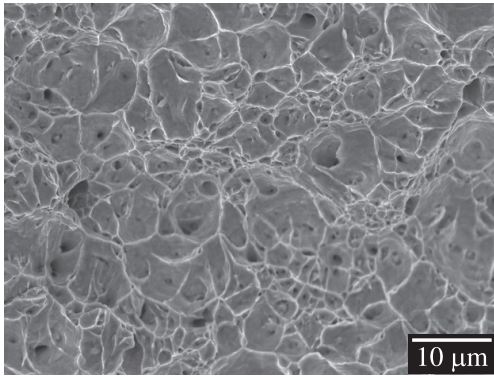

(a)

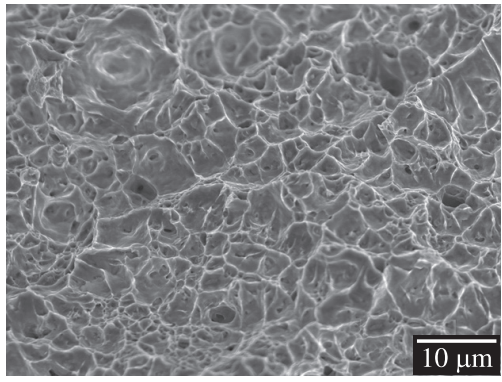

(b)

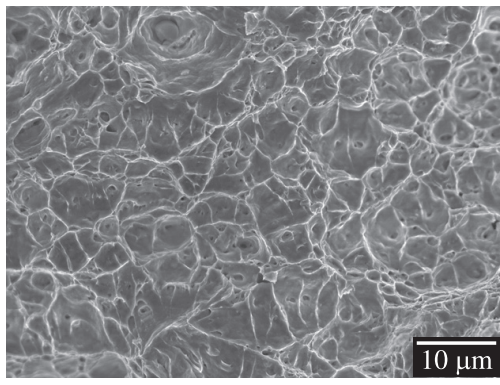

(c)

Figure 5. SEM micrographs of tensile fracture surfaces of a) steel A; b) steel B; and c) steel C.

\section{Conclusions}

Three kinds of initial microstructures with ferritepearlite, ferrite-martensite and acicular ferrite were intercritically annealed at $820^{\circ} \mathrm{C}$ for 10 minutes followed by water quenching to produce FMDP steels. The mechanical properties and microstructures of these three FMDP steels were compared. The main conclusions were summarized as follows:

1) The properties and microstructures of FMDP steels varied significantly with the different initial microstructures, which were due to the differences in the initial microstructures before intercritical annealing;

2) The FMDP steel produced from acicular ferrite microstructure had tensile strength of $704 \mathrm{MPa}$, yield ratio of 0.68 , Charpy impact energy of $310 \mathrm{~J}$ at $-20{ }^{\circ} \mathrm{C}$, uniform elongation of $13.5 \%$ and total elongation of $22.7 \%$, which had the optimum combinations of strength, toughness and deformability compared with that derived from the ferrite-pearlite and ferrite-martensite initial microstructures; and

3) The FMDP pipeline steels overcame the limits of the properties of high-strength pipeline steels with poor deformation ability, which had the optimum combinations of strength, toughness and deformability, and provided a good candidate for the pipeline steels with strain-based design used in severe geological environments.

\section{References}

1. Bakhtiari R and Ekrami A. The effect of bainite morphology on the mechanical properties of a high bainite dual phase (HBDP) steel. Materials Science and Engineering A. 2009; 525:159165. http://dx.doi.org/10.1016/j.msea.2009.07.042

2. Kumar A, Singh SB and Ray KK. Influence of bainite/martensitecontent on the tensile properties of low carbon dual-phase steels. Materials Science and Engineering A. 2008; 474:270-282. http:// dx.doi.org/10.1016/j.msea.2007.05.007

3. Saeidi $\mathrm{N}$ and Ekrami A. Comparison of mechanical properties of martensite/ferrite and bainite/ferrite dual phase 4340 steels. Materials Science and Engineering A. 2009; 523:125-129. http://dx.doi.org/10.1016/j.msea.2009.06.057

4. Nouri A, Saghafian H and Kheirandish S. Effects of silicon content and intercritical annealing on manganese partitioning in dual phase steels. Journal of Iron and Steel Research,
International. 2010; 17(5):44-50. http://dx.doi.org/10.1016/ S1006-706X(10)60098-2

5. Ahmad E, Manzoor T, Hussain N and Qazi NK. Effect of thermomechanical processing on hardenability and tensile fracture of dual-phase steel. Materials and Design. 2008; 29:450-457. http://dx.doi.org/10.1016/j. matdes.2006.12.022

6. Bayram A, Uğuzv A and Ula M. Effects of microstructure and notches on the mechanical properties of dual-phase steels. Materials Characterization. 1999; 43:259-269. http://dx.doi. org/10.1016/S1044-5803(99)00044-3

7. Sarwar M and Priestner R. Influence of ferrite-martensite microstructural morphology on tensile properties of dual-phase steel. Journal of Materials Science. 1996; 31:2091-2095. http:// dx.doi.org/10.1007/BF00356631

8. Erdogan M and Tekeli S. The effect of martensite particle size on tensile fracture of surface-carburised AISI 8620 steel with dual phase core microstructure. Materials and Design. 2002; 23:597-604. http://dx.doi.org/10.1016/S02613069(02)00065-1

9. Demira B and Erdoğan M. The hardenability of austenite with different alloy content and dispersion in dual-phase steels. Journal Materials Processing Technology. 2008; 208:75-84. http://dx.doi.org/10.1016/j.jmatprotec.2007.12.094

10. Davies RG. The deformation behavior of a vanadiumstrengthened dual phase steel. Metallurgical Transactions A. 1978; 9A:41-52. http://dx.doi.org/10.1007/BF02647169

11. Saikaly W, Bano X, Issartel C, Rigaut G, Charrin L and Charaï A. The effects of thermomechanical processing on the precipitation in an industrial dual-phase steel microalloyed with titanium. Metallurgical Materials Transactions A. 2001; 32A:1939-1947. http://dx.doi.org/10.1007/s11661001-0006-0

12. Salehi AR, Serajzadeh $S$ and Taheri AK. A study on the microstructural changes in hot rolling of dual-phase steels. Journal of Materials Science. 2006; 41:1917-1925. http:// dx.doi.org/10.1007/s10853-006-4486-6

13. Zhao MC, Yang K and Shan YY. Comparison on strength and toughness behaviors of microalloyed pipeline steels with acicular ferrite and ultrafine ferrite. Materials Letters. 2003; 57:1496-1500. http://dx.doi.org/10.1016/ S0167-577X(02)01013-3

14. Wang W, Yan W, Zhu L, Hu P, Shan YY and Yang K. Relation among rolling parameters, microstructures and mechanical properties in an acicular ferrite pipeline steel. Materials and Design. 2009; 30:3436-3443. http://dx.doi.org/10.1016/j. matdes.2009.03.026 
15. Hu YY, Zuo XR, Li RT and Wang ZW. Comparison of two different rolling processes on microstructure and properties of ferrite-bainite dual-phase pipeline steels. Advanced Materials Research. 2011; 197-198:724-729. http://dx.doi.org/10.4028/ www.scientific.net/AMR.197-198.724

16. Li RT,Zuo XR, HuYY, Wang ZW and Hu DX. Microstructure and properties of pipeline steel with a ferrite/martensite dual-phase microstructure. Materials Characterization. 2011; 62:801-806. http://dx.doi.org/10.1016/j.matchar.2011.05.013

17. Das D and Chattopadhyay PP. Influence of martensite morphology on the work-hardening behavior of high strength ferrite-martensite dual-phase steel. Journal of Materials Science. 2009; 44:2957-2965. http://dx.doi.org/10.1007/ s10853-009-3392-0

18. Kim NJ and Thomas G. Effects of morphology on the mechanical behavior of a dual phase $\mathrm{Fe} / 2 \mathrm{Si} / 0.1 \mathrm{C}$ steel. Metallurgical Transactions A. 1981; 12A:483-489. http:// dx.doi.org/10.1007/BF02648546

19. Bag A, Ray KK and Dwarakadasa ES. Influence of martensite content and morphology on tensile and impact properties of high-martensite dual-phase steels. Metallurgical and Materials Transactions A. 1999; 30A:1193-1202. http://dx.doi. org/10.1007/s11661-999-0269-4

20. Gündüz S. Effect of chemical composition, martensite volume fraction and tempering on tensile behaviour of dual phase steels. Materials Letters. 2009; 63:2381-2383. http://dx.doi. org/10.1016/j.matlet.2009.08.015

21. Zhang CL, Cai DY, Zhao TC, Fan YC and Liao B. Simulation of hot-rolled dual-phase weathering steel $09 \mathrm{CuPCrNi}$. Materials Characterization. 2005; 55:378-382. http://dx.doi. org/10.1016/j.matchar.2005.08.003

22. Rudnizki J, Böttger B, Prahl U and BleckW. Phase-field modeling of austenite formation from a ferrite plus pearlite microstructure during annealing of cold-rolled dual-phase steel. Metallurgical and Materials Transactions A. 2011; 42A:2516-2525. http:// dx.doi.org/10.1007/s11661-011-0626-y

23. Garcia CI and Deardo AJ. Formation of austenite in $1.5 \mathrm{pct}$ Mn steels. Metallurgical Transactions A. 1981; 12A:521-530. http://dx.doi.org/10.1007/BF02648551
24. Xiao FR, Liao B, Ren DL, Shan YY and Yang K. Acicular ferritic microstructure of a low-carbon Mn-Mo-Nb microalloyed pipeline steel. Materials Characterization. 2005; 54:305-314. http://dx.doi.org/10.1016/j.matchar.2004.12.011

25. Zhang CL, Cai DY, Liao B, Zhao TC and Fan YC. Microstructure and mechanical properties of dual-phase weathering steel 09CuPTiRe. J Mater Sci. 2004; 39:4393-4396. http://dx.doi.org/10.1023/B:JMSC.0000033436.06575.aa

26. Nakagawa A, Koo JY, Thomas G. Effect of vanadium on structure-property relations of dual phase $\mathrm{Fe} / \mathrm{Mn} / \mathrm{Si} / 0.1 \mathrm{C}$ steels. Metallurgical Transactions A. 1981; 12A:1965-1972.

27. Souza MM, Guimaraes JRC and Chawla KK. Intercritical austenitization of two Fe-Mn-C steels. Metallurgical Transactions A. 1982; 13A:575-579. http://dx.doi.org/10.1007/ BF02644421

28. Yi JJ, Kim IS and Choi HS. Austenitization during intercritical annealing of an Fe-C-Si-Mn dual-phase steel. Metallurgical Transactions A. 1985; 16A:1237-1245. http://dx.doi. org/10.1007/BF02670328

29. Kumar AN and Basu SN. Manganese partitioning and dual-phase characteristics in a microalloyed steel. Journal of Materials Science. 1991; 26:2089-2092. http://dx.doi. org/10.1007/BF00549172

30. Kim NJ and Nakagawa AH. Effective grain size of dual-phase steel. Materials Science and Engineering A.1986; 83:145-149. http://dx.doi.org/10.1016/0025-5416(86)90181-3

31. Davies RG. Early stages of yielding and strain aging of a vanadium-containing dual-phase steel. Metallurgical Transactions A. 1979; 10A:1549-1555. http://dx.doi.org/10.1007/BF02812021

32. Davies RG. Influence of martensite composition and content on the properties of dual phase steels. Metallurgical Transactions A. 1978; 9A:671-679. http://dx.doi.org/10.1007/BF02659924

33. Erdogan M. The effect of new ferrite content on the tensile fracture behaviour of dual phase steels. Journal of Materials Science. 2002; 37:3623-3630. http://dx.doi. org/10.1023/A:1016548922555 